Öztürk, Ahmet Erdi. "Turkey's Diyanet under AKP rule: from protector to imposer of state ideology?." Southeast European and Black Sea Studies 16, no. 4 (2016): 619-635.

Received 03 Jun 2016, Accepted 01 Sep 2016, Published online: 20 Sep 2016

\title{
Turkey's Diyanet under AKP rule: from protector to imposer of state ideology?
}

\begin{abstract}
This article focuses on the complex relations between Turkey's Presidency of Religious Affairs (the Diyanet) and the AKP in the last decade. It claims that the Diyanet, under AKP rule, has been transformed into a pliable state apparatus geared towards implementing the political ideology of the ruling cadre. In exploring this recent transformation, it analyses the ways in which this institution's role has become synchronized with the ruling party's discourses and actions, by giving examples from recent discussions on gender, social media, political economy, and relations with other social groups.
\end{abstract}

Keywords: The Diyanet; religion; Islam; Turkey; AKP; ideological state apparatus; secularism

Since 2002, Turkey has been ruled by a single-party government, an unparalleled development in a society characterised historically by a weak and fragmented party-system and long periods of unstable coalition government. Over this period, the ruling Justice and Development Party (Adalet ve Kalkınma Partisi / AKP) has established itself as the dominant force in Turkish politics and society and the most successful political party in Turkey's electoral history. The influence of its founding leader, Recep Tayyip Erdoğan, cannot be underestimated in this context. While it is true that the AKP retains an autonomous party structure, it is fair to say that Erdoğan's dominance means that the AKP and its leader have become almost synonymous.

Scholars have noted how the AKP has used its dominant political position to direct state resources to underwrite the political success of its leading cadres (Görener and Ucal 2011). Moreover, many state institutions, from the judiciary to the police service, have established intricate relations with the governing party and its undisputed leader, and have been gradually reshaped to both reflect and promote the AKP's ideological aims. Although this political instrumentalisation has been welcomed by many who support Erdoğan and his movement, it has nevertheless not gone uncontested within Turkish society.

This article focuses on the political instrumentalisation of one important arm of the Turkish state by the AKP during the last decade - the Presidency of Religious Affairs (hereinafter the 
Diyanet). Within the state, the Diyanet is an administrative unit required by law to maintain a secular structure, which is nevertheless principally charged with the management of religion, particularly the regulation of Islamic (read: Sunni Muslim) faith and practice, religious education, and the construction and maintenance of places of prayer (Gözaydin 2009). A core claim of the article is that under AKP rule, the ideological work of the Diyanet as a fundamental state apparatus has been recast by the ruling cadre to advance a much more clearly defined and more explicitly ideological political agenda at the best of the ruling party. It argues that, while the Diyanet has always served as a principle vehicle for reinforcing state ideology in modern Turkey, its political salience and ideological purposes have undergone significant transformation since the early 1980s, and most radically under the AKP. This study aims to explore this recent transformation of the Diyanet and the ways in which its role has synchronized with the ruling party's discourses and actions.

To ground the analysis, this article draws on Louis Althusser's (2014) distinction between ideological and repressive state apparatuses. The latter consist of agencies under direct state control, such as the army, the police, the judiciary, and the prison system, which have recourse to coercion in order to control society. By contrast, ideological state apparatuses - for example the education system, the media, or religious institutions - while not directly under formal state control, nevertheless still serve to transform societies according to the main principles and aims of the dominant political elite by exercising more non-coercive and indirect forms of social control, such as ideology and manufactured consent. Althusser pointed to the Roman Catholic Church as an exemplary ideological state apparatus, advancing a comprehensive ideological frame through non-coercive means such as cultural persuasion and indoctrination (Althusser 2014).

Since its foundation, the Diyanet has functioned as a fundamental ideological apparatus within the Turkish state. During the early Republican era, this was reflected in its role as the primary vehicle for the justification and consolidation of Turkey's rather unique secular state-structure and the Kemalist project of establishing state hegemony over all religious activity and education. After 1980, its ideological work entered a new phase, being deployed as an increasingly important tool in Turkish foreign policy. During the AKP period, the ground has shifted again, and the Diyanet's remit and range of activity have expanded significantly. This latest shift cannot be understood outside the AKP's broader political project of establishing dominance over the entire Turkish state during the last decade. Additionally, the Diyanet's 
current activities and fatwas (Islamic scholarly opinions) have been very controversial in terms of human rights and democracy, and have caused uproar among certain segments of Turkish society.

Since 1937, Turkey has been defined officially as a secular state, albeit with a Muslim-majority population. However, secularism in the Turkish context is distinctive, a product of its particular historical experience and development (Kuru 2009, 162-195). Both the Ottoman heritage and its founding fathers' apprehension were decisive factors in the evolution of Turkish secularism (Gözaydın 2009, 13-17) and set Turkey's experience apart from that of other modern secular states (Somer 2007). The Diyanet was established as an ideological state apparatus within this context, with the primary purpose of ensuing the tight management and control of religion by Kemalist elites within the new secular state structure (Gözaydın and Öztürk 2014, 10-11). The Diyanet's principal raison d'etre, therefore, was tutelary. Its core mission was to stand as the primary line of defence of the Kemalist state against an imagined threat from religion.

The Diyanet's ideological work, however, has been neither static nor narrowly-focused. Two distinct historical shifts have occurred in this context: the first in the period following the September 1980 coup d'état, and the second since the rise of the AKP. The 1983 restoration of civilian rule in Turkey was accompanied by the emergence of the Turkish-Islamic synthesis (TIS), a particular blend of Islamo-nationalist ideological work somewhat paradoxically championed by the military-dominated state. Under the provisions of the 1982 constitution, the Diyanet took on the responsibility for administering aspects of the state propagation of the the TIS, among other things, especially in relation abroad, in those countries with significant Turkish-immigrant populations. Under the AKP, the Diyanet's role has evolved yet again, and over this period it has gradually added to its existing functions the responsibility of enforcing the ruling party's particular ideology, both at home and abroad. This period marks the transformation of the Diyanet from a functional ideological state apparatus to a very pliable and an imposer one, which regulates and steers Turkey's society according to the political decision makers' ideology and daily political strategies.

This article proceeds as follows. It begins with a brief discussion of the historical context, and in particular the evolution of Turkey's distinctive brand of secularism, one that is at once grounded philosophically in Western secular discourses but at the same time informed by Turkey's unique historical development, and in particular its Ottoman heritage. Some of the 
contradictions and challenges in the actual implementation of Turkish secularism that have emerged out of this tension are also unpacked. Secondly, it will outline the specific structure and function of the Diyanet, with a particular focus on its activity, aims and areas of control. Finally, it will analyse the Diyanet's transformation under the AKP, with a discussion of key events that exemplify ways in which its ideological work has been recast in this time.

\section{Debates around secularisation}

The relation between church and state, and between the appropriate boundaries between the religious and the political, have for centuries posed a challenge for scholars and statesmen alike. Seminal contributions by Durkheim and Weber over a century ago sparked a wave of scholarship in the $20^{\text {th }}$ century exploring the relationship between religion and modernity. Much of this work posited a fundamental opposition of modernity and religion, and predicted that the practice of the latter would inexorably decline as the former progressed (Wilson 2001, 43-48; Warner 2010, 32; Ben-Porat 2013, 6-12). This idea of the 'death of religion' rests on the assumption that as societies modernise, increasing commitments to scientific rationality and individual autonomy lessen the influence of 'the sacred' and of religiously-oriented institutions, leading to an inevitable process of secularisation (Wilson 2001, 212).

This basic perspective has held, even as other contributors have sought to elaborate the sources and consequences of secularisation over the more recent past. Habermas (2005, 46), for example, understands secularisation as much an ideology or comprehensive worldview (adopted mostly in the Western world) as a natural product of social development. Additionally, since the end of the cold war in particular neo-liberal globalisation has been theorised by some scholars as a virtually irresistible mechanism that will inevitably spread secularising modernity world-wide. This global socio-economic transformation is said to pave the way for a new kind of secular liberal global society to emerge and consolidate over time (Cox 2013). The core contention argued throughout modern secularisation theories has been not that religion will disappear as such, merely that it will become entirely a feature of an individual's private conscience with little purchase in the public sphere. State and society, in this view, move to promote individual merit and autonomy over traditional forms of role ascription and patrimonial promotion, and religion inexorably recedes into the background (Berger 1967, 3-28). 
Religion, however, has clearly not followed the predicted path (Ben-Porat 2013, 4). Prominent pro-secularist Peter Beyer notes that although contemporary culture and politics seems to be secular, the impact of religion is still significant (Beyer 2013, 15). Many scholars, therefore, have called into question the principal assumptions underpinning most modernisation theories of secularisation (e.g. Casanova, 2001; Asad, 2003; Ben Porat, 2013). David Martin's critique is particularly telling for the discussion of the distinctiveness of Turkish secularism. Martin asserts that in essence, almost every country's experience of secularisation will be at some level distinct, since every single culture has its unique transformation processes in terms of religion (Martin 1995, 474) and religion, society and politics, are interrelated with heritage, experiences and culture. This insight is a critical one for the Turkish/Ottoman case.

In Turkey, despite the best efforts of the secular Republican elite over many decades, religion has indeed remained a motive force. It is critical to note that Turkish secularism differs from most Western forms, in three distinct ways. Firstly, Turkish secularism has always been something of a hybrid, drawing on Western philosophical discourse and the legacies of the Ottoman period at the same time. Secondly, secularisation in the West (perhaps with the notable exception of France) has largely been understood as an organic, 'bottom up' social phenomenon largely working on, rather than emanating from, the state. In Turkey, in contrast, the state has been both the progenitor and the political and social focal point of secularism and secularisation from the very beginning. Lastly, the founding fathers of Turkey chose to use the term laiklik ${ }^{\mathrm{i}}$ (from the French, laicité) to explain the relation between state and religion, rather than that of secularism. This choice emphasises the particular Ottoman/Turkish notion that it is the proper and legitimate function of the state to take the lead in setting the parameters of rightful religious conduct within society.

\section{Different assumptions about Turkey's position in discussions on secularization}

Turkey's historical journey has been idiosyncratic, and the impact of that historical development remains salient today in almost every dimension of social and political life. This is especially true of religion, which has remained a highly ideologically-charged and vexed issue and where a broad consensus within the society has failed to materialise (Keyman 2010, 143). As mentioned, Turkey has officially been a secular (laic) state since 1937. On first blush this would lead us to assume the existence of a distinct separation of religion and state since this time. Nevertheless, it is clear that in reality the situation is much less clear cut. In fact, the 
particular structure and function of the Diyanet as a legally secular administrative structure within the Turkish state responsible for religious affairs is instructive (Gözaydın 2009, 19-21). The incorporation of the Diyanet within the Turkish state indicates not a separation of religion and state, but an attempt at hegemonic management of religion by the state for the purpose of not only limiting its influence and pertinence within the public sphere but of pacifying it more generally.

It is this point particularly that distinguishes Turkey from France, the closest comparator case and the model that Kemalist elites most clearly looked to in the early Republican period. In France, while a strict separation is maintained in the public domain, religious practice and order is managed and controlled independently by the religious institutions themselves. Turkey's Ottoman heritage is a crucial factor in understanding the Turkish particularities (Mardin 1983), and all explanation of this arguably unique structural interpolation between religion and state in Turkey, as in many other aspects of the modern republic, must incorporate the legacies of the Ottoman period in the analysis (Gözaydın and Öztürk 2014, 10).

It is worth noting that understanding of the relation between the state and religion in the Ottoman period is itself debated, with three broad schools of thought providing somewhat different interpretations. These differences emerge, for the most part, from the distinctive reading of the Ottoman legal situation, its political codes of practice, and the precise function of religious institutions within the state that each school adopts (Gözaydın 2009, 13). The first approach points to the clear distinction in Ottoman legal theory and practice between the earthly and spiritual domains embodied in the legal order: spiritual/ecclesiastic law (şer'i hukuk), based on Islamic sharia law, and customary law (örfi hukuk), which assumed that much legitimate conduct could only be ascertained within a particular social setting. While asserting that this distinction was not a clear separation of religion and state in the sense that modern secular theory would have it, defenders of this approach do claim that the distinction was a product of gradual reform and that in this sense it constituted a form of gradual secularisation. Seen this way, developments in the Republican period (and in the antecedent Young Turk period, 19081918) can be interpreted as an acceleration of a reform process that had already been developing over a long period in the Ottoman past (Mardin 2003, 207-232). For instance, Halil İnalc1k argues that, contrary to general belief, the authority of the Ottoman Sultans did not derive exclusively from their position as Caliph, but rather from military and legal sources as well. 
Thus, in this view, there relationship between the legal and spiritual areas is one of overlap, as they were fundamentally different sources of power (İnalc1k 1973).

The second approach rejects the notion that the legal order of the Ottoman state was divided in this way at all. Rather, the contention is that the distinctions observed in practice constituted two sides of the same coin. Ottoman sultans articulated both legal and spiritual powers by using two titles (emperor and caliph) at the same time, and established an integrated state structure, with earthly and spiritual powers. The Ottomans state was thus possessed of a unified Sunni Islamic institutional code, albeit with two registers: one legal and one spiritual (Gözaydın 2009, 14). The core of this idea is that Islam is an inclusionary religion which regulates all areas of life, including statecraft. In this view, the Republican experience constitutes a fundamental break with the past (Başgil 1998, 193-195).

The last approach draws a thread of continuity from the Ottoman period to the present that highlights a particular Ottoman sensibility in respect of the political management of religion. Here, the emphasis is on the enduring aspect of the Ottoman/Turkish state tradition that sees the management of religion by the centre as a core element of rightful and legitimate state conduct. During the Ottoman period, the Caliph/Sultan had absolute authority to appoint or expel the head of religious affairs, known as the Shaykh al-Islam (Şeyhülislam). Moreover, the Shaykh al-Islam ran religious affairs on behalf of the Sultan (Gözaydın 2009, 14-15). This means that the head of the state did not permit any independent religious authority and therefore controlled religious issues by using an office which was subordinated to him. This was obviously a contrast to Western church practice in the same historical period (Kuru 2009).

\section{Turkey's choice: controlling and instrumentalising religion via the Diyanet}

This article draws heavily on the last of these aforementioned perspectives; namely that there was a particular Ottoman sensibility in respect of the political management of religion and that the modern Turkish state has inherited it to a significant extent (Gözaydın and Öztürk 2014). This is not to say that this inheritance was either complete or unmediated - the Republican founders had a complicated approach to religion. On the one hand, they recognised the obvious importance of religion in Turkish society (Mardin 2003, 234), and the need to deal with that social reality on its own terms, at least for the time being. On the other hand, the founding elites were determined to limit the power of religion and religious authorities in Turkish society and 
to introduce a legitimating framework for state and political authority that completely excluded religious justifications. In so far as the early Kemalist elite were in fact convinced that religious movements and practices were in fact anathema to the vision of a modern, civilised state and society, their natural inclination was to dominate and pacify it. But it is also critical to understand, that Kemalist elites had few blueprints to work from in managing this process and that they were addressing the issue of religion in politics that was quite distinct to that of the Western experience. For this reason, their capacity to fully embrace the Western model of secularism was limited and they naturally drew to models from the Ottoman experience to find a practical solution. The result was a political instrument and social apparatus aimed at instrumentalising religion through state action (Çarkoğlu 2006).

To understand this background, the concept of laiklik (laicité) is vital. Laicité/laicism/laic is the term used to describe state control of religion in the public sphere, as opposed to secularism, which implies merely the separation of state and religion. Laiklik (laicité) was the concept selected by Turkey's Republican elite in all statutes and other legal regulations which shape its core today (Davison 2003, 335-342). Originally, the term lâdini has been used. The etymology of this word is identical to that of laicité, but had clear antireligious overtones. The term laiklik was chosen instead because as a rather unfamiliar term with no clearly negative overtones, it was seen as less intimidating for the general population. Laiklik itself has never had one single, unambiguous interpretation in Turkey, but in general it is widely understood that it reflects a sense that the state should not be totally blind to religious issues, but also should never favour one particular religion over another. Thus Islamic practice was carried over in the society from the Ottoman state to the new Turkish Republic and allowed Republican elites to declare a new structural order, without losing hegemonic power over religion. At the same time, the older Ottoman tradition of state management of religion was retained.

The Diyanet was thus established in the new Republic as a multi-functional political instrument and apparatus aimed at instrumentalising religion through state action (Bottoni 2007, 178180).It was established in March 1924 in the wake of the abolition of the Ottoman caliphate and its associated institutions, including the Şeriye Vekaleti (Ministry of Religious Affairs) and the Evkaf (Pious Foundations) (Gözaydın and Öztürk 2014, pp 10-11). The new Republican elite established the Diyanet in a deliberate fashion, so as to signal ideological commitments resolutely. First, the new administrative unit's legal status was grounded in the authority of the state, signalling that religion was now de jure subordinate to the sovereign secular Turkish state. 
Secondly, administratively speaking the new arrangements were a clear bureaucratic downgrade (from ministerial level) in religious administration, while at the same time the Diyanet was the only such unit placed directly under the control of the prime minister. Even the name Diyanet was selected purposefully, so as to indicate the mission of the unit to administer strictly matters of 'faith and worship' and not religion per se, thus implicitly stripping Sunni Islam of solidly political status (Gürpınar and Kenar 2016, 64).

According to İştar Gözaydın, the state decree (Law 429) establishing the Diyanet was a significant step in the construction of the secular system in Republican Turkey. This was not only because of the abovementioned symbolic stripping of Islam's status as a religion in the public realm (Gözaydın 2009, 23-25), but also because it clearly brought faith and worship into a subordinate position under the sovereign secular state, particularly through its provisions according the Grand National Assembly of Turkey (GNAT) and the cabinet full authority over religious affairs. At the same time, it established the basis on which the Diyanet was literally founded as an ideological state apparatus, in Althusser's terms. Its tutelary mission was both to inculcate the Kemalist elite's conception of a 'proper' and 'modern'(i.e. private) religious practice on the population but also to neutralise any threats to the Kemalist nation-building project emanating from religious authority by instrumentalising it.

Law 429 thus emerged as part of a radically accelerated process of state-led modernisation that had already been nascent under the old order (particularly the Young Turk period) through social and political reform on Western lines. For Kemalist elites, the adoption of the Latin script, and Western modes of dress, education, politics and religion were avatars of civilised modernity, as in the West (Kadığlu 1996). Kemalist elites lay the blame for Ottoman decline at the feat of the 'backward' and reactionary religious mentality of Islam as they felt it was practiced in the empire, and so were doggedly determined to eliminate this by instrumentalising religion through state control.

The Diyanet has grown considerably since its founding in 1924. According to official statistics, in 2015 it administered approximately 86,762 registered mosques and employed more than 117,378 staff, include Quran instructors, muezzins ${ }^{i i}$, and other religious workers, all of whom are treated as civil servants with regular salaries. Over time, the Diyanet has become consistently more institutionalised and its mission has expanded considerably. The first significant shift came in the 1960s. (Gözaydın 2009). Under the provisions of the 1961 
constitution, the GNAT was mandated to provide special legislation to recast the ideological work of the Diyanet, particularly in terms of a new mission to 'enlighten' society about the proper conduct of religion and the moral aspects of the Islam within a fundamentally rationalistmodern frame. This 1965 legislation clearly indicates how the post-196 order positioned the Diyanet as an ideological apparatus of the state, with a renewed mandate of modernisation and enlightenment (Gözaydın and Öztürk 2014, 19-20). Furthermore, it indicates how significant religion remained in Turkey even 40 years after the founding of the secular republic, and how little 'progress' Kemalist elites felt they had made in accomplishing laiklik in practice.

Turkish implementation of laiklik has three different functions. From the beginning of the early republican period to the 1982 constitution, laiklik was organised mainly via the Diyanet and other state apparatuses. The first function was about bringing religion under control of the state (Yavuz 1999, 194-195). The founding elites prohibited all religious communities and activities, in order to transform and modernise the country. Secondly, the founding elites' ideologies and their understanding of laiklik, meant that they had to obliterate all traces of religion in the public sphere, in terms of matching the contemporary outlook of Western countries. The Diyanet was used to relegate religion only to the private sphere. Moreover, the dominant Kemalist political ideology, through its adherents, managed and regulated Sunni Islam, the major religious sect in Turkey, by basically taking a firm grip on religion via the Diyanet. Finally, the institution was instrumentalised as nation builder through incorporation into the propaganda system especially after the 1980s.

\section{Transformation of the Diyanet during the AKP period}

As noted previously, the main missions of the Diyanet have been, since the beginning of the early republican period, to propagate an understanding of Sunni Islam and its moral values among the public, to support nation-building, and to protect the state and society from undesirable faith-based ideologies. This is best understood as a tutelary posture. Its position did not change, but its authority and duties were expanded in the 1982 constitution, which come into force after 1980 coup d'etat. The constitution gave the Diyanet the duty to carry out its mission within the framework of the principles of the Turkish understanding of secularism, but also added achieving national solidarity and integrity to the institutions remit (Gözaydın and Öztürk 2014). This development reflected the view of the 1980-1983 military junta that religion and nationalism should be fused (the so-called Turkish-Islamic Synthesis) in Turkey in order 
to prevent the emergence of radical discourses, particularly of the left, which had caused tremendous violence in Turkey in the 1960s and 1970s. The Diyanet's role was expanded to propagate the Turkish-Islamic Synthesis. Reflecting the post-1983 political concern with radical and extremist ideologies, Diyanet was also charged with a role in addressing these as well (Bardakoğlu 2004, 368). Additionally, in the new order, Diyanet's mission was expanded to include promotion of Turkish Islam abroad, especially in countries with high Turkish immigrant populations. Further legislation in 1983 gave statutory protection to the Diyanet from attempts to close it down, a reflection of challenges the body had come under in the previous period from leftist extremists (Gözaydın 2009).

Since the beginning of the 1980 's, the Diyanet has regulated Muslim practices and thinking, not only inside Turkey's borders, but also in other Turkic countries and countries with large Turkish and Muslim populations. Since the early 1980's, the Diyanet has sent imams to Europe, the Balkans and the Middle East, to counterbalance the influence of other Islamic communities on Turkish Muslims, and to maintain their loyalty to the Turkish state. It was during these years that many Turkish citizens migrated to Europe as labour migrants, and their temporary sojourn turned into a permanent residency through time. To counter undesirable Islamic influences, the Diyanet aimed to propagate Sunni Islam through the mosques and compulsory classes on Islam, with a strong emphasis on ethics, human rights, and the individual citizen's duties towards the state. However, the Diyanet's grip on international affairs is not limited to migrants with a Turkish background (Öktem 2010) and thus it started to play a political role as a promoter of Turkish state policies.

The ground shifted again after 2002. The background to this is the emergence in the 1990s, of the Islamist Welfare Party (Refah Partisi) under the leadership of Necmettin Erbakan in the 1990s (Öniş 1997, 745-751). When Erbakan became prime minister as head of a coalition government in 1996, hard-core supporters of laicism, as part of the military administration, again indirectly intervened and the government was removed in early 1997 and the Welfare Party later banned in what was known as the 'February 28 process.' Erdoğan had been a member of the party, and after it was banned played a formative role in the development of one of the AKP as a quasi-successor party (Keyman and Gümüşcü 2014). Under Erdoğan's leadership, the party won a landslide victory in the 2002 elections (Keyman and Gümüşcü 2014). Even as he rose to the officially non-partisan presidency of Turkey after his election to 
that office in 2014 Erdoğan ceased to limit his role in AKP affairs as he is constitutionally required to do (Öztürk 2014).

The rare electoral success of the AKP enabled the party to govern Turkey without coalition partners for 13 years and to get rid of military tutelage (Esen and Gümüşcü 2016). Although the AKP's decisive victory caused some concern in Turkey's secular quarters, after four years of rule, the party started to develop policies paying attention to Turkey's sensitive issues. Economic development, foreign policy compatible with the European Union and liberal reforms were among its prominent successes (Öniş and Yılmaz 2009 pp. 7-14). Therefore, for the first time in Turkish political history, a religious-rooted ruling party was successfully conducting domestic and foreign policy. Erdoğan and the AKP promoted and implemented proEuropean Union and pro-democratization reforms until the 2011 elections. However, after this election, the AKP's policies and Erdoğan's discourse took something of an 'authoritarian turn', and the party's appeals became ever more populist and extreme. While some indicators of this potential had been in evidence well before 2011, the turn took many students of Turkish politics by surprise and the subsequent decline in standards of Turkish democracy are generally seen as a tremendously regressive development (Esen and Gümüşcü 2016; Aydın-Düzgit 2016).

It is in this context that the Diyanet has become one of the most politicized and disputed ideological tools of all the state apparatuses in Turkey. Moreover, over the last decade its structure and activity have become increasingly synchronized with the policies of both Erdoğan and the AKP. Indeed, to an unprecedented extent, the Diyanet now contributes actively to the public discussion in Turkey of all manner of political and social affairs, but does so largely as a 'mouthpiece' of the ruling party. While continuing its traditional functions as outlined above, under the AKP, Diyanet has taken on additional roles, including restoring sites of Ottoman heritage and supporting the construction of mosques in other countries such as Albania, the Netherlands, and Germany (Öktem 2010). The Diyanet's emergence as a pliable ideological state apparatus has been facilitated by two key factors. The first is the AKP's political skill at transforming apparently political neutral reform and democratisation efforts into an authoritarian capacity to exert dominance over the entire Turkish state structure since 2011 (Özbudun 2014, 156-167). The second factor is the personal approach of the Diyanet's current Chairman, Prof. Dr. Mehmet Görmez. Görmez has arguably been one of the most high-profile chairmen in the institution's history. Görmez has frequently addressed the media about a great variety of issues including socially and politically important matters. 
In 2003, Turkey's then president, the arch-secularist Ahmet Necdet Sezeriii appointed Prof. Dr. Ali Bardakoğlu as the Chairman of the Diyanet and Bardakoğlu held that position until late 2010. During this period, Görmez was one of his deputies. Bardakoğlu's administration arguably kept a significant distance from politics. Besides, a series of reforms had been conducted in 2010 to abolish the ban on the Islamic headscarf ${ }^{\mathrm{iv}}$ and in that reforming process, Erdoğan, laying emphasis on the Diyanet, proposed that the Diyanet should be consulted. However, according to Bardakoğlu consulting the Diyanet on legislation violates the principle of secularism. Furthermore, he also stated that Islam does not require Muslim women to wear headscarves. ${ }^{v}$ Neither welcoming nor confirming his statements, the AKP government ended Bardakoğlu's tenure and appointed Görmez in his place. Görmez has been more devoted to fulfilling the AKP's demands. Thus, the AKP and the Turkish state structure shaped and absorbed each other in a reciprocal way, rendering the AKP more powerful on gaining the ability to control and instrumentalise the Diyanet as its own ideological state apparatus and political imposer in a wide range of social and political spheres. ${ }^{\mathbf{v}}$

2010 was another turning point for the Diyanet. Legislative reforms at this time both expanded the mission of the organisation and dramatically strengthened its bureaucratic and administrative capacity. This is important, because increased capacity provides the Diyanet with greater ability to affect policy not only in Turkey but also in foreign countries. These reforms came after ten years of exponential growth after the 2002 election of the AKP. In less than a decade, its budget has quadrupled to over \$2 billion, and it now employs almost 120,000 people, making it one of Turkey's largest state agencies. Moreover, whereas once its employees were predominantly secular career civil servants, increasingly more openly pious Muslim recruits have been brought into its ranks. Additionally, since 2011 the Diyanet has been issuing halal certificates for food products. In 2012, the Diyanet opened a television station, Diyanet $T V^{\text {vii }}$ which only broadcasts thematically Sunni Islam based programmes. The programmes mostly impose dominant political structure's policies. In 2016, the first religious kindergarten was opened by the cooperation with the Diyanet and the Diyanet Foundation. ${ }^{\text {vii }}$ Since 2012, the Diyanet also has been producing fatwas on demand with a free telephone hotline service that provides mostly Sunni Islamic guidance on everyday matters. This means that the Diyanet can easily become involved in daily life practices by answering ordinary questions. ${ }^{\text {ix }}$ Additionally, Görmez has proven happy to address current affairs, and has invariably tacked close to the AKP line. In this regard, during the AKP period, the Diyanet openly supported the AKP by instrumentalising its sermons. For instance, the day before the June 2015 parliamentary 
election, a number of imams urged their flock not to vote for certain parties but for Muslims which was directly referring to the AKP. ${ }^{\mathrm{x}}$

There are some other obvious and significant examples of this, including a conformity between the ruling party's daily agenda and the Diyanet's discourses, which has increased during the last ten years. Currently, on the one hand, the Diyanet tries to reshape the system by dominating religion and religious institutions. On the other hand, it aims at controlling and leading the masses. In some cases, the Diyanet takes its lead from the ruling political structure: in others it is the main actor. In the following section, I analyse the parallel discourses and recommended policies of Erdoğan, the AKP governments, and the Diyanet, to illustrate this conformity.

\section{Popular debates over the Diyanet during the AKP period}

Before giving some prominent examples of the parallel reactions of the ruling political structure and the Diyanet, I would like to stress that most of these examples concern the conservative religious-based implementations and discourses of the AKP and Erdoğan. The authoritarian shift of the political structure in Turkey has an eclectic relationship with religion and the conservatives. That is to say, the Diyanet, as an ideological state apparatus, is the highest authority on religion, supplying social and religious legislation for the AKP and Erdoğan's political manoeuvres. The data that are subject to analysis cover a total number of 199 public speeches delivered by Erdoğan and 92 reactions, fatwas, and sermonettes of the Diyanet in the run up to and the immediate aftermath of the 2002 general election. The timing of the analysis, which covers the period between December 2002 and mid-August 2016, is particularly chosen as corresponding to a period in which the AKP reportedly governed Turkey single-handedly with firmly-established control over almost all the state system. The examples and discussions below are around various and the most visible issues such as gender, daily life practices of Turkish society, political economy, and some milestone political moments. It can be seen that the interventions of the Diyanet in these situations were not solely to control and regulate religion: the Diyanet was used to suppress dissent against the AKP and Erdoğan.

The first example concerns a very controversial issue. On 28 May 2012, Mr. Erdoğan told a gathering of the women's branches of his party that "each abortion is one Uludere" - a reference to Turkish Air Force strikes on a village called Uludere, on the Iraqi border, which killed 34 civilians on 28 December 2011. ${ }^{\text {xi }}$ The Uludere incident was a critical juncture for Turkey as it stalled the Turkish-Kurdish peace process and caused protests all around the country. This discussion came at a time when diverting the political debate to another topic were more than 
necessary. Abortions, said Erdoğan, were, "a sneaky plan to wipe the country off the world stage". Moreover, he added that "I am a prime minister who opposes caesarean births, and I know all this is being done on purpose. I know these are steps taken to prevent this country's population from growing further. I see abortion as murder, and I call upon those circles and members of the media who oppose my comments: You live and breathe Uludere. I say every abortion is an Uludere". xii Only five days after Erdoğan's problematic declarations, Görmez told the country that "a mother should never give any decision about abortion, which is absolutely an assassination, because a mother is only a carrier". Moreover, Görmez said that "in the medical committee, which decides on abortions, a religious functionary should be a member". xiii This incident shows that the Diyanet's statements can be used to divert attention away from politically contentious issues, to an empty debate that would otherwise occupy very little media space These two statements, however, occupied Turkish political and social life for some time and women's rights activists protested against both Erdoğan and the Diyanet. The "my body, my decision" campaign emerged after this incident. ${ }^{\text {xiv }}$

Erdoğan's interventions on gender-related issues and women rights continued, with constant support by the Diyanet after each incident. As a current example, Erdoğan said in a speech on 24 May 2014: Our religion granted women with a position: motherhood. It granted mother one more time; laid heaven under her feet. So, a mother's foot has to be kissed. But you cannot express this to the feminists who deny motherhood. Those who understand are enough, we move on with them. ${ }^{\mathrm{xv}}$ The Diyanet had already made a declaration on this issue in 2008, on International Women's Day, when it published the following pronouncement: "Feminism is indecency and contradicts our religion". xvi This could be an indicator that the Diyanet is merely pursuing the current ideology. Both the dominant political structure and the Diyanet share almost the same outlook and they can be seen verifying and supporting each other at different times. According to them, the important duty of women is to be mothers and other explanations and options are not appropriate. Likewise, in the last decade, the Diyanet has issued fatwas which directly or/and indirectly support the worldview of the AKP and Erdoğan. For instance, Erdoğan's 2013 discourse on a TV programme in which he complained about his encounter with mini-skirted teenagers holding hands with their boyfriends. He stated that although it was disturbing, he forced himself to respect their rights. ${ }^{\text {xvii }}$ Similarly, Diyanet's 2016 fatwa asserted that plucking eyebrows and wearing makeup are not permissible. ${ }^{\text {xvii }}$ In the same fatwa, the Diyanet mentioned that people should be careful to avoid making other people feel 
uncomfortable because of their inconvenient behaviours, and ruled that "newly engaged couples may not meet or hold hands." ${ }^{\text {xix }}$

The third example is about economic policy. As is known, shortly after the AKP took office, it showed no hesitation in fully adopting neo-liberal policies entrusting national resources and the economic future of the country directly to foreign capital, and the non-fettered workings of the market (Yeldan 2007, 3). This pro-neoliberal policy approach has been evident throughout the party's journey and it is usual to find the Diyanet in a supportive position during controversial issues. At this point it should be noted that not only have the headquarters of the Diyanet been supporting the AKP's and Erdoğan's discourses and policies, but local branches too are giving normative support. For instance, in 2008, when 120 workers who had been fired because of their membership of the industrial union, shouted slogans targeting Erdoğan, the Diyanet's Düzce local branch stated: "slowing down the work, damaging the workplace, actions that cause a decrease in profits put workers under religion responsibility", ${ }^{\mathrm{xx}}$ emphasizing that striking is a sin. Thus without any sign from the dominant political structure, the Diyanet channels itself into political, social and economic issues, in strict agreement with the approach taken by the AKP.

The fourth example is one of the most notorious political debates in Turkey within recent years: the conflict between the AKP and the Gülen Movement. ${ }^{\text {xi }}$ From 2002, the AKP has created a huge coalition that embraces different groups, such as liberals, scholars, columnists, key members of the financial sector, Muslim and non-Muslim groups, ethnic minorities and civil society organizations. Among these social coalition partners of the AKP, the Gülen Movement should be defined as a special ally. Whereas the other coalition partners had supported the AKP and its policies in one or two areas, the Gülen Movement has been actively working with the AKP both in Turkey and abroad. The Gülen Movement supported the AKP by using its intellectual platforms, the media, and public figures. Meanwhile, through the AKP government, members of the Gülen Movement have managed to reach top positions in the state bureaucracy. Although, this coherent coalition seemed to last for a long time, the relationship worsened after 2010. The biggest tension began with the 17 December and 25 December 2013 corruption investigations that involved Erdoğan and some ministers of the cabinet. According to Erdoğan, the Gülen Movement was actually trying to carry out a civil coup d'état through these judicial investigations. It is known that many Gülen Movement volunteers had been holding important positions in the state bureaucracy. After the corruption investigations Erdoğan claimed that the Gülen Movement was not a civil society organization, but an illegal one that was working 
against the elected government and the state. Thus, Erdoğan started to establish judicial policies against both Fethullah Gülen and the movement's voluntary activities, including schools, intellectual platforms and charity organisations. Print and social media characterized the government's actions as a witch-hunt against the Gülen Movement. ${ }^{\text {xii }}$ The conflict is still alive and the Diyanet has a certain position in this discussion. For instance, Görmez said in one of his speeches on 5 May 2015, "this Movement's desire for political power damages not only the state structure, but also Islam itself. In this regard, we as the Diyanet will never ever let this instigation enter into the Mosques and in our nation. In this situation, one of the main aims of the Diyanet is to act together with our nation, our government and our state, and without any doubt it will play its part". xxiii Although the conflict between the AKP and the Gülen Movement is utterly political, the Diyanet is clearly taking sides with the AKP and Erdoğan, by instrumentalising its religious authority, in order to criminalize the other group.

Another example is about the parallel discourses of Erdoğan and the Diyanet on the matter of the social media. After the Gezi Protests ${ }^{\text {xxiv }}$ and the corruption investigations in 2013, Erdoğan has perceived the social media as one of the biggest public enemies, not only for the state structure but also for every single individual in Turkey. He has blocked dozens of websites including Twitter, Facebook and YouTube. Moreover, after blocking Twitter, in 2013 Erdoğan said that "let people say whatever they want, we will take care of this ourselves". He called Twitter a "menace to society" and on May 2013, Erdogan vowed to "eradicate" Twitter (Parkinson et al. 2014). It is possible to give more examples about Erdoğan's attitude regarding the social media. It is obvious that he sees the social media standing as a power against his political aims and the national security of Turkey. The Diyanet takes the same position as Erdoğan. On 14 May 2016, the Diyanet held a forum entitled "Social Media and the Family in the Context of Privacy" as part of its training and guidance on solidifying the family institution and raising awareness among family members of the rights and responsibilities that they have, to avoid potential damage by the social media. The forum featured discussions on issues including the social media and waning privacy, the impact of the social media on marriage, and the impact of the social media on family breakup. In his opening speech, Görmez mentioned that Unfortunately, every kind of lies, imposture, defamation, humiliation and gossip is located in social media and thus they may damage all of humanity. In this regard, we, as religious authorities, have to write a social media catechism, which will give the main principles of how to use social media. This is another significant example of ideological harmony between the Diyanet and the dominant political structure. Furthermore, it also shows how the Diyanet 
supports the political discourse of Erdoğan, justifying itself with religious terminology and concepts.

The last example is about one of the biggest millstones of contemporary Turkey's history. Not to put too fine a point on it, the night of July 15, 2016 was one of the most remarkable moments of the contemporary Turkish political life. Without a chain of command, a medium size group of flag officers of Turkey's army attempted a coup d'état primarily against the Erdoğan, and AKP government. ${ }^{\mathrm{xx}}$ It was a teaser attempt for a country which had been suffered by military tutelage periods and number of different types of military regimes. Although, the first couple of hours of the coup attempt brought about perturbation among Turkey's citizens, the government achieved a success in countering the coup attempt and forced it to fail within almost twenty hours of being initiated. Moreover, the massive number of civilians, who took to the streets to defend both democracy and elected political structures after President Erdoğan's FaceTime call, played an important role in this response. Despite the fact that having averted the coup attempt is perceived as an important accomplishment today, it must still be noted that about 300 people lost their lives and 1000 wounded which is an absolute tragedy for any country in 2016. Notwithstanding, great many things are still ambiguous about the coup attempt and most of the statements of the coup plotters are discordant, pre-emptively President Erdoğan and then almost all the other political actors, public intellectuals, scholars, veteran journalists and vast majority of Turkey's society come to an agreement about the instigator of it: Fethullah Gülen and his Movement. During this failed coup attempt the Diyanet played a significant role more than other state institutions and apparatuses.

First of all, during the coup attempt Görmez had issued an order to all imams of the Turkish Republic to go to their mosques and call upon the people to do the same. This is when the public heard the first sala prayer being read at mosques around the country almost simultaneously all night. Traditionally, sala prayers are read to announce a funeral at the mosque. During the Ottoman era, sala prayers were called to announce difficult times during wars. The voice of the imams is known as the single voice that has the power to reach all the people instantaneously. Furthermore, Diyanet sent a text message to the phones of the all preaches, who are government employees themselves, asking them to recite the sala prayer at all mosques. Some preachers just read the sala prayer periodically, while others also read announcements to the public informing them where to assemble and encouraging them to be courageous. 
Secondly, after the coup attempt the Diyanet announced that none of the preachers provide Islamic buried serves to the coup suspects. Furthermore, a day after the failed coup attempt Görmez declare that While bombs were raining down from war planes, we first tried to keep the morale of the people high. Later we read the funeral prayers for our democracy martyrs. ${ }^{\text {xxvi }}$ At last, Görmez also declared Fethullah Gülen as the head of terrorist organisation who has been convincing people by the name of the God and Islamic values. ${ }^{\text {xxvii }}$

In the light of these selected examples and the previous explanations about the expansion of the Diyanet's activity areas, it can be said that the Diyanet has gained the following new positions and duties during the AKP period: a) supporting and legitimizing via religious approval mechanisms the discourses and actions of the AKP and particularly Erdoğan; b) diverting the political dimension of popular debates from the dominant political structure to itself and by doing so diffusing the pressure on these structures; c) supressing opposition movements and actors, and finally; d) converting contentious dominant structure policies to religious-based, indisputable facts which cannot be openly and widely discussed, as they are bound by Islam itself. Previously, the Diyanet was bounded by state regulations and it was a state institution. However, during the AKP era, with the authoritarian shift towards one-man-rule, the state became the Party and the Party became Erdoğan. Therefore, the Diyanet indirectly aligned itself to the de facto ruler of the country: the president himself.

\section{Conclusion}

Proceeding from an historical analysis, this article has aimed to shed light on how the Diyanet has been transformed from a protector to a very efficacious and convenient apparatus for state ideology over the last thirty years. It has particularly focused on the Diyanet's character as imposer of policy during the AKP period. Therefore, firstly, it explained Althusser's term "ideological state apparatus" and demonstrated that the Diyanet has been one of the most influential ideological state apparatuses of Turkey since the very beginning of the early republican period. Secondly, it revealed the secularisation discussions in the mostly Western oriented world and pointed to Turkey's unique situation among these discussions. It analysed Turkey's understanding of secularisation/laicité, which has been implemented as management and regulation of religion by the dominant political actors in Turkey.

Moreover, it also explained the increase in the Diyanet's duties during the AKP period, thanks to the interlaced structure of the Party and the Turkish state. This article showed that the 
Diyanet, as an ideological state apparatus, started its journey as a protector of the Turkish state's understanding of Islam and secularism. But it was transformed into a promoter, with the task of spreading Turkish nationalism and Islamic moral values both inside and outside of Turkish borders. Lastly, the Diyanet has been converted into an "ideological state apparatus", which has been imposing the AKP's and Erdoğan's political and ideological preferences very effectively since 2002. As an illustration of this, the article presented six different examples, around gender related issues, daily life practices of Turkish society, political economy and key milestone political moments which have shaped the Diyanet's outlook and capacity, anchoring it within Turkey's current political structure.

Consequently, despite to be an ideological state apparatus is an ontological necessity for the Diyanet under the understanding of Turkish secularism, this structural characteristic has reach a pick position during the AKP period. One may deduce that while the leading political figures of AKP are getting more and more authoritarian and dominant, the Diyanet is going to both legitimize and impose these new political preferences by instrumentalising its religion based authority.

\section{References}

Althusser, L. 2014. On the reproduction of capitalism: Ideology and ideological state apparatuses. London: Verso Books.

Asad, T. 2003. Formations of the secular: Christianity, Islam, modernity. Stanford, California: Stanford University Press.

Aydın-Düzgit, S. 2016. 'De-Europeanisation through discourse: a critical discourse analysis of AKP's election speeches'. South European Society and Politics 21, no. 1: 45-58.

Banchoff, T. 2008. Religious pluralism, globalization, and world politics. Oxford: Oxford University Press on Demand.

Bardakoglu, A. 2004. 'Moderate perception of Islam' and the Turkish model of the Diyanet: the president's statement 1. Journal of Muslim Minority Affairs 24, no. 2: 367-374.

Başgil, A. F. 1998. Din ve Laiklik. [Religion and Secularism]. İstanbul: Kubbealtı Publishing, 
Ben-Porat, G. 2013. Between state and synagogue: the secularization of contemporary Israel (Vol. 42). New York: Cambridge University Press

Beyer, P. 2013. Religions in global society. London: Routledge

Bottoni, R. 2007. The origins of secularism in Turkey, Ecclesiastical Law Journal. 9, no. 2:175-186.

Casanova, J. 2001. Religion, the new millennium, and globalization. Sociology of religion. 62, no. 4: 415-441.

Cox, H. 2013. The secular city: Secularization and urbanization in theological perspective. New Jersey: Princeton University Press

Çarkoğlu, A. 2006. Religion and politics in Turkey. London: Psychology Press.

Davison, A. 2003. Turkey, a" secular" state? The challenge of description, The South Atlantic Quarterly. 102, no.2: 333-350.

Esen, B., and Gumuscu, S. 2016. Rising competitive authoritarianism in Turkey. Third World Quarterly 1-26.

Fox, J., Sandler, S., and Sandier, S. 2004. Bringing religion into international relations. New York: Palgrave Macmillan.

Fuller, G. E. 2008. The New Turkish Republic. Turkey as a Pivotal State in the Muslim World. Washington: United States Institute of Peace

Görener, A. Ş., and Ucal, M. Ş. 2011 The Personality and Leadership Style of Recep Tayyip Erdoğan: Implications for Turkish Foreign Policy. Turkish Studies. 12, no. 3:357-381.

Gözaydın, İ. 2009. Diyanet. [the Diyanet]. İstanbul: İletişim Yayınları.

Gözaydin, I., and Öztürk, A. E. 2014. Religion in Turkey. Turkey Institute Policy Report. 9780-9931268-0-2. London: Turkey Institute Press.

Gözaydin, İ. 2008. Religion, Politics, and the Politics of Religion in Turkey. New York: Palgrave Macmillan. 159-176.

Gürpinar, D., and Kenar, C. 2016. The Nation and its Sermons: Islam, Kemalism and the Presidency of Religious Affairs in Turkey. Middle Eastern Studies 52.vol. 1: 60-78.

Habermas, J. 2005. Pre-political foundations of the democratic constitutional state? The dialectics of secularization: On reason and religion. San Francisco: Ignatius Press.

Hanson, E. O. 2006. Religion and politics in the international system today. New York: Cambridge University Press.

Haynes, J. 2007. Introduction to international relations and religion. London: Pearson Education Press. 
İnalc1k, H. 1994. The Ottoman Empire: The classical age 1300-1914. London: Phoenix Press.

Kadioğlu, A. 1996. The paradox of Turkish nationalism and the construction of official identity. Middle Eastern Studies. 32, no. 2: 177-193.

Keyman, E. F. 2010. The CHP and the" Democratic Opening": Reactions to AK Party's Electoral Hegemony. Insight Turkey.12, no. 1: 91-109.

Keyman, E. F. 2014. The AK Party: Dominant party, new Turkey and polarization. Insight Turkey. 16, no. 2: 19-31.

Keyman, E. F., and Gumuscu, S. 2014. Introduction. In Democracy, Identity, and Foreign Policy in Turkey. London: Palgrave Macmillan

Kuru, A. T. 2009. Secularism and state policies toward religion: the United States, France, and Turkey. New York: Cambridge University Press.

Mardin, Ş. 1983. Din ve ideoloji. [Religion and Ideology]. İstanbul: İletişim Yayınları.

Mardin, Ş. .2003. Türk Modernleşmesi, Makaleler 4. [Turkish Modernization, Essays 4]. İstanbul: İletişim Yayınları.

Martin, J. 1995. Screening the sacred: religion, myth, and ideology in popular American film, Westview Press, Colorado.

Parkinson, J., Schechner, S., and Peker, E. 2014 Turkey's Erdogan: One of the world's most determined Internet censors. Wall Street Journal, 2.

Onis, Z. 1997. The political economy of Islamic resurgence in Turkey: The rise of the Welfare Party in perspective. Third World Quarterly, 18, no. 4: 743-766.

Öktem, K. (2010) New Islamic actors after the Wahhabi intermezzo: Turkey's return to the Muslim Balkans. New Islamic actors after the Wahhabi intermezzo: Turkey's return to the Muslim Balkans: Oxford: European Studies Centre, Oxford.

Öniş, Z., and Yilmaz, Ş. 2009. Between Europeanization and Euro-asianism: Foreign policy activism in Turkey during the AKP era. Turkish Studies, 10, no. 1: 7-24.

Özbudun, E. 2014. AKP at the crossroads: Erdoğan's majoritarian drift. South European Society and Politics. 19, no. 2:155-167.

Öztürk, A. E. 2014. The Presidential Election in Turkey: History and Future Expectations, Contemporary Southeastern Europe. 1, no.2: 110-118.

Petito, F.,and Hatzopoulos, P. 2003. Religion in international relations: The return from exile. New York: Palgrave Macmillan.

Somer, M. 2007. Moderate Islam and Secularist Opposition in Turkey: implications for the world, Muslims and secular democracy. Third World Quarterly. 28, no. 7: 1271-1289. 
Warner, R. 2010. Secularization and its discontents. London: Bloomsbury Publishing,

Wessels, D. 2009. Religion and globalization. Routledge handbook of religion and politics, 323.

Wilson, B. 2001. Salvation, secularization, and de-moralization, Oxford: Blackwell,

Yavuz, M. H. 1999. The assassination of collective memory: The case of Turkey. The Muslim World. 89, no.3/4: 193-206.

Yeldan, E. 2007. Patterns of adjustment under the age of finance: the case of Turkey as a peripheral agent of neoliberal globalization. PERI Working Papers. 86.

\footnotetext{
${ }^{i}$ Laicité is one of the most important concepts of French constitutional theory. It refers to the absence of religious and other faith-based involvement in government affairs, especially the prohibition of religious influence in the determination of state policies. The Turkish understanding and implementation is quite different to this classical definition. In Turkey's case, the founding fathers and their followers have preferred to use the term laiklik to define one of the important qualifications of the state, in the constitutions after 1937 that of 'active neutrality'. For more details, see Gözaydın 2008

ii The person who leads the call to prayer.

iiihttp://www.hurriyetdailynews.com/secularisms-introductioncommemorated.aspx?pageID=438\&n=secularisms-introduction-commemorated-2006-02-06 .

${ }^{\text {iv }}$ For further details, please see; http://www.bbc.com/news/world-europe-11880622 .

${ }^{v}$ http://bipartisanpolicy.org/wp-content/uploads/2015/10/BPC-Turkey-Transformed.pdf .

vihttp://www.turkeyanalyst.org/publications/turkey-analyst-articles/item/463-the-rise-of-diyanet-thepoliticization-of-turkey's-directorate-of-religious-affairs.html.

vii http://www.diyanet.tv/en .

viii For more information see; http://www.trthaber.com/haber/turkiye/diyanetin-anaokulunda-egitim-basliyor266048.html

${ }^{\text {ix }}$ Some of these questions and answers are quite absurd. For instance, in 2015, the Diyanet issued a fatwa stating water is the preferred method of cleaning oneself after using the commode, but toilet paper is an acceptable substitute if a water source is unavailable. For further details about this fatwa see http://www.hurriyetdailynews.com/turkeys-top-religious-body-allows-toilet-

paper.aspx ?pageID $=238 \&$ nid $=80671 \&$ NewsCatID $=341$

${ }^{\mathrm{x}}$ http://www.zaman.com.tr/gundem_cuma-hutbesi-siyasallasinca-camiler-karisti_2298576.html .

${ }^{x i}$ For further details about the Uludere incident, see; http://www.economist.com/node/21556616.

xii http://www.hurriyetdailynews.com/abortion-sparks-raging-debate-inturkey.aspx?pageID=238\&nID=21740\&NewsCatID=339.

xiii http://www.aljazeera.com.tr/haber/kurtaj-sinirlamasina-diyanet-destegi .

xiv http://bianet.org/english/women/138850-my-body-my-decision.

xv http://www.theguardian.com/world/2014/nov/24/turkeys-president-recep-tayyip-erdogan-women-not-equalmen .

${ }^{\mathrm{xvi}}$ http://www.hurriyet.com.tr/diyanet-feministleri-kizdirdi-8434696

xvii https://www.youtube.com/watch?v=LMmmaOJp8ts

xviii http://www.gercekgundem.com/guncel/187500/bu-da-diyanetin-cimbiz-fetvasi

${ }^{x i x}$ http://www.bbc.com/turkce/haberler/2016/01/160108 diyanet fetva tartisma

${ }^{x x}$ http://haber.sol.org.tr/sonuncu-kavga/muftuluk-hutbe-okuttu-grev-caiz-degil-haberi-42663
}

xxi The Gülen Movement is a network organised under the ideas of the Islamic scholar and preacher Fethullah Gülen, who is the indisputable moral and ideal vanguard of the movement. The Gülen Movement has a contemporary Islamic core, which is transnational and voluntary. It is said that the Hizmet Movement has expanded to almost 160 countries in the world by using its voluntary workers in its educational centres. In this respect, it is related to both Turkey's and the world's economic, social and political issues. Gülen Movement, Gülen Community, Voluntary Movement and the Hizmet are among different names given to this group in various 
settings. Although the movement itself prefers to call itself the Hizmet Movement; in this study I prefer to use the term "the Gülen Movement", respecting the main academic principles and to protect individual objectivity.

xxiihttp://www.hurriyetdailynews.com/akp-hizmet-fight-risks-turning-into-witchhunt.aspx ?pageID=449\&nID=59933\&NewsCatID=470

xxiii https://www.youtube.com/watch?v=k67JL_BJv0w

xxiv For more information on Gezi seests https://www.amnestyusa.org/sites/default/files/eur440222013en.pdf

${ }^{x x v}$ For detailed information about the issue see http://www.mirror.co.uk/news/world-news/what-happened-turkeyattempted-coup-8432395

xxvi For the declaration of Görmez see http://www.dw.com/en/fears-grow-in-turkey-after-failed-military-coup/a$\underline{19408635}$

xxvii Fort he declarations of Görmez see http://www.dinihaberler.com/diyanet/gormez-feto-nun-neden-kafiroldugunu-acikladi-h97011.html 